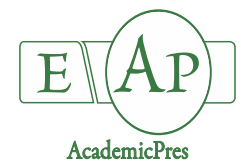

Jasso-Gándara SN et al. (2020)

Notulae Botanicae Horti Agrobotanici Cluj-Napoca 48(3):1130-1140

DOI: $10.15835 /$ nbha48311955

Research Article

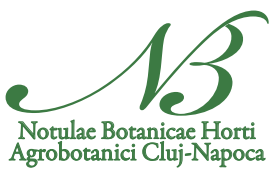

\title{
Plants used as medicinal in Güémez, Tamaulipas, north-eastern Mexico
}

\section{Sindi N. JASSO-GÁNDARA ${ }^{1}$, Eduardo ESTRADA-CASTILLÓN ${ }^{1}$, Juan A. ENCINA-DOMÍNGUEZ ${ }^{2 *}$, José Á. VILLARREAL- QUINTANILLA 3 , José R. ARÉVALO SIERRA ${ }^{4}$}

\author{
${ }^{1}$ Universidad Autónoma de Nuevo León, Facultad de Ciencias Forestales, Apartado postal 41, Linares, 67700, Nuevo León, \\ México; sindi_jasso@outlook.com; aeduardoestradac@prodigy.net.mx \\ ${ }^{2}$ Universidad Autónoma Agraria Antonio Narro, Departamento de Recursos Naturales Renovables, Buenavista, Saltillo 25315, \\ Coahuila, México; jaencinad@gmail.com (" ${ }^{*}$ corresponding author) \\ ${ }^{3}$ Universidad Autónoma Agraria Antonio Narro, Departamento de Botánica, Buenavista, Saltillo 25315, Coahuila, \\ México; javillarrealoo@hotmail.com \\ ${ }^{4}$ Universidad de La Laguna, Facultad de Ciencias, Departamento de Botánica, Ecología y Fisiología Vegetal, Tenerife 38206, Islas \\ Canarias,España; jarevalo@ull.edu.es
}

\begin{abstract}
The use of medicinal plants in Mexico has a diverse and deeply-rooted tradition concerning. Plants play an important role in traditional medicine among the inhabitants of Güémez, Tamaulipas in northeastern Mexico. With the aim of obtaining quantitative information on the plants and their uses as medicinal sources, semi-structured interviews with 113 local residents were taken. In addition, Informant Consensus Factor (ICF) and Use Value (UV) were calculated. A total of 85 species of medicinal plants belonging to 44 families were identified. The most common families were Asteraceae, Lamiaceae and Euphorbiaceae. The most used part of the plant was the leaf and the most frequent preparation method was boiling, preparing as an infusion. A total of 50 medicinal uses were registered. Fever had highest ICF (0.93), whereas, according to UV, the most important plants were Artemisia ludoviciana Nutt., Mentha spicata L., Matricaria recutita L. and Achillea millefolium $\mathrm{L}$. The information generated strengthens traditional knowledge, bringing new species and uses to the country's records for future phytochemical studies that could lead to new medicines.

Keywords: ethnobotany, medicinal plants; quantitative analysis; traditional medicine; use value

\section{Introduction}

About $80 \%$ of the world's population relies on traditional medicine to satisfy primary health care needs (Bermúdez et al., 2005; Ayyanar and Ignacimuthu, 2011; Panyaphu et al., 2011). The World Health Organization has registered approximately 21,000 plant species for medicinal uses around the world (Malla et al., 2015). Medicinal plants are an important source of current drugs. About $25 \%$ of the world's prescription drugs come from plants (Bulut and Tuzlaci, 2013).
\end{abstract}

Received: 10 Jun 2020. Received in revised form: 20 Aug 2020. Accepted: 24 Aug 2020. Published online: 08 Sep 2020. 
Mexico has a diverse and deeply-rooted tradition concerning the use of medicinal plants (EstradaCastillón et al., 2018). In Mexico, there are more than 23,400 vascular plants and 5,000 species are used for medicinal purposes and the most important families are Asteraceae, Lamiaceae, Fabaceae, and Euphorbiaceae (Casas et al., 2001; Camou-Guerrero et al., 2008; Alonso-Castro et al., 2012). Also is ranked sixth in the world regarding greatest cultural diversity (Mercado, 2013), as it has 62 ethnic groups (Juárez-Rosete et al., 2013). Most ethnic groups use medicinal plants because of their efficiency, tradition and low costs (Kayani et al., 2015; Tribess et al., 2015). In particular, rural areas contribute with most knowledge about medicinal plants (Kayani et al., 2015). These plants help communities to survive in remote areas (Gómez, 2012).

Nowadays, it's recognized that in Mexico and many countries around the world the transmission of knowledge regarding the use of medicinal plants from old to new generations is declining are experiencing loss of useful plants due (Quesada, 2008; Calvo et al., 2011; Hassan-Abdallah et al., 2013) as well as losing entire villages and local populations due to lack of work, education and medical care (Panyaphu et al., 2011). This fact is also a reality in rural communities because of globalization and the use of allopathic medicine (EsquivelGarcía et al., 2018). Therefore, it is important to rescue this knowledge to prevent the loss of ethnomedical traditions, which is a scientific and cultural heritage important for future generations.

The municipality of Güémez, located in the northeast of Mexico, covers $1.5 \%$ of the Tamaulipas state. Its economy is based on agriculture (citrus, safflower, bean, maize, henequen and sorghum), cattle raising and forestry production also take place on smaller scale. However, there are no local inhabitants selling medicinal plants. The local people live in houses of 'adobe' (building material made from soil and often organic material), wood and concrete. Health services are scarce with little medicine and few doctors. Some villages do not have drainage, clean water, electricity, so migration is commonplace due to lack of security, education and employment.

The objective of this study is to know the most commonly used medicinal plants and their uses by the inhabitants of the municipality of Güémez with the purpose to revaluing and saving this traditional knowledge in this region of Mexico.

\section{Materials and Methods}

\section{Studyarea}

The municipality of Güémez is located within the Sierra Madre Oriental and is part of the centralwestern region of State of Tamaulipas (Figure 1) $\left(24^{\circ} 06^{\prime}-23^{\circ} 41^{\prime} \mathrm{N}\right.$ and $99^{\circ} 30-98^{\circ} 45^{\prime} \mathrm{W}$ ), its altitude is from 200 to $2,800 \mathrm{~m}$. It covers $1,204.55 \mathrm{~km}^{2}$, has 43 localities with a population of 15,659 inhabitants, of which $80 \%$ live in urban areas and $20 \%$ in small villages called 'ejidos'. The climate of the region is temperate to sub-humid, in mountainous areas and semi-dry to very warm in the lowlands. The mean annual temperature ranges from 12 to $26^{\circ} \mathrm{C}$ and the annual rainfall is 600 to $1,100 \mathrm{~mm}$ (INEGI, 2009).

\section{Fieldwork}

Wild and cultivated medicinal species in the study area were collected. Plant samples obtained were pressed and dried according to the method described by Sánchez-González and González (2007). Specimens were identified by the authors through the Manual of the Vascular Plants of Texas (Correll and Johnston, 1970), scientific names were consulted in The Plant List (http://www.theplantlist.org/). The complete collection of specimens was included in the CFNL herbarium (acronym according to Thiers, 2011). We include the common name in Spanish for all plants species registered during interviews.

\section{Data collection}

Direct interviews were conducted with the villajes called "ejidos" Los San Pedros, La Esperanza, San Cayetano, Graciano Sánchez, La Yerbabuena, Constitución del 17, Servando Canales, San José de Las Flores 
and Viento Libre. A total of 113 inhabitants, 32 men and 81 women with ages ranging between 30 and 90 years old, were interviewed individually. The interviewees were housewives, cattle ranchers, loggers, farmers and healers. All the interviews were carried out through visits to homes and in the field. The information for the ethnomedicinal species was recorded in Spanish, as it is the only language spoken in the region, through semistructured interviews. The questions were about common plant names, medicinal use, part of plant used, methods of preparation and route of administration.

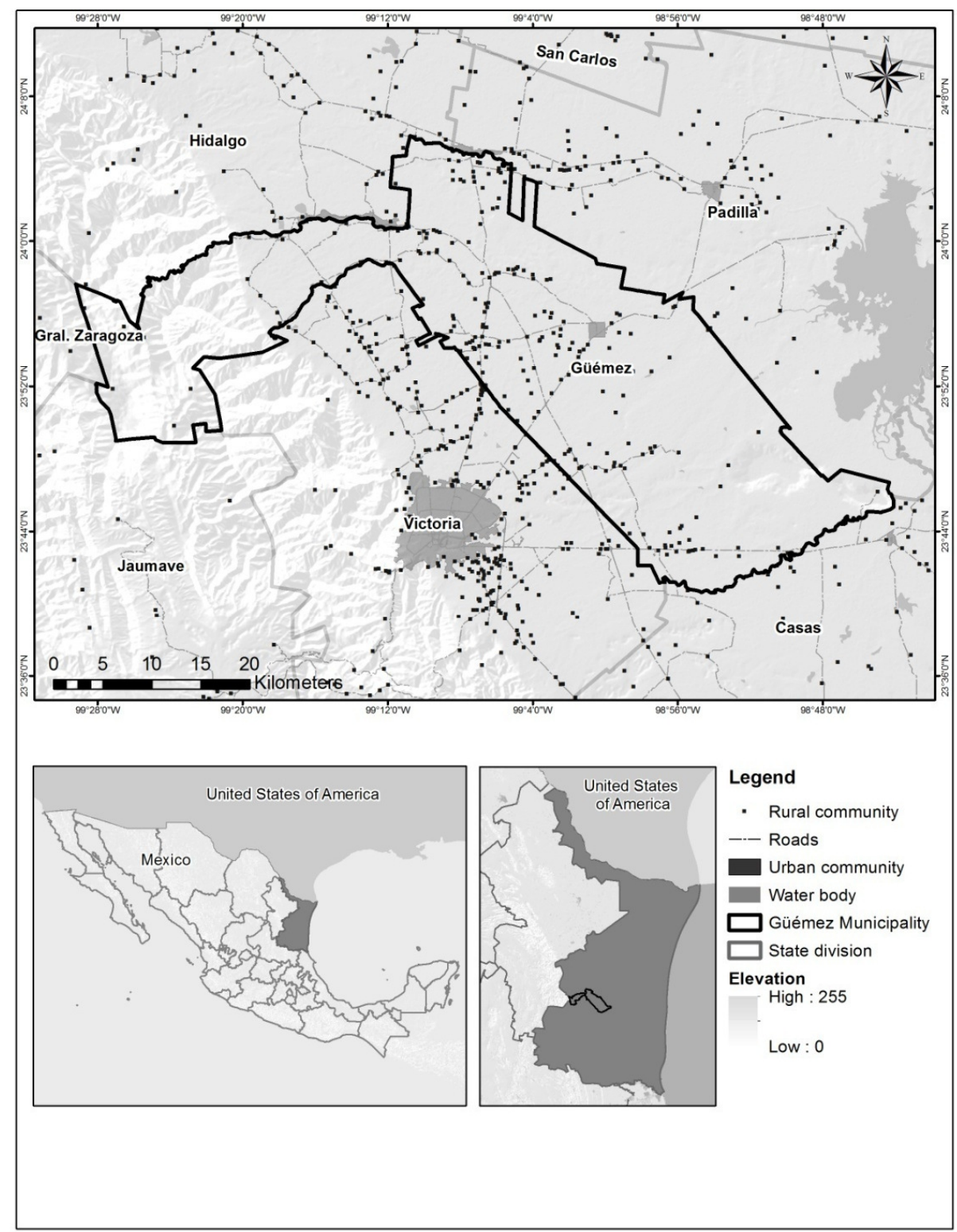

Figure 1. Location of the municipality of Güémez, Tamaulipas, Mexico

\section{Data analysis}

The diseases treated with medicinal plants were classified into 13 categories: (1) gastrointestinal system (gastritis, poor digestion, constipation, intestinal ulcer, diarrhea, vomiting, stomach inflammation, flatulence, nausea, stomach pain, lack of appetite, toothache, mouth infection, bad breath), (2) respiratory system (bronchitis, asthma, cough), (3) blows and wounds (external blows, wounds, internal blows, sunken 
fontanelles, extraction of thorns), (4) dermatological (rashes, ringworm, herpes virus, baldness, fungus feet), (5) endocrine system (diabetes, cancer), (6) nervous system (insomnia, headaches, nerves, stress, dizziness), (7) muscular skeletal system (rheumatism, osteoporosis), (8) circulatory system (hemorrhoids, varicose veins, anemia, impaired immune system), (9) fever (high temperature, typhoid), (10) intestinal parasites (worms), (11) ophthalmologic (eye infections), (12) urinary system (Kidney, urinary infections), (13) female reproductive system (Menstrual cramps, infertility, abortion).

The ICF adapted by Heinrich et al. (1998), is calculated according to following formula: ICF = (Nur-

$\mathrm{Nt}$ ) / (Nur -1) where Nur refers to number of citations of uses given in each category and $\mathrm{Nt}$ to number of species used. This method is used to test the homogeneity of information. The ICF offers a range of $0-1$, where high values (about 1) are obtained, when there is a well-defined selection criterion in the community and/or if information is exchanged between informants, and the values are low (near zero) if plants are chosen at random or if there is no exchange of information about their use among informants.

The use value (Trotter and Logan, 1986), demonstrates the relative importance of locally known species and is calculated according to the following formula: $\mathrm{UV}=\mathrm{U} / \mathrm{N}$, where $\mathrm{U}$ refers to number of citations per species and $\mathrm{N}$ to number of informants.

\section{Results}

\section{Richness of medicinal plants}

According to the results of specimen identification, 85 species with medicinal uses, belonging to 41 families were reported by interviewees. Among them, 45 species are cultivated and 40 species are wild. The most common families of medicinal plants are Asteraceae (17.64\%), Lamiaceae (11.76\%), Euphorbiaceae (7.05\%) and Rutaceae (4.70\%). During the study, 126 samples were collected in the study area. Plants used for medicinal purposes in Güémez are presented in Appendix 1 in alphabetical order according to family and scientific name.

The most commonly mentioned species were Artemisia ludoviciana $(\mathrm{n}=51)$, Mentha spicata $(\mathrm{n}=44)$, Matricaria recutita $(\mathrm{n}=37)$, Achillea millefolium $\mathrm{L} .(\mathrm{n}=30)$ and Ruta graveolens $\mathrm{L} .(\mathrm{n}=28)$. Herein, we report eight native species of Mexico considered as new records of traditional medicinal plants in this country, which are: Boerhavia spicata Choisy, Cirsium texanum Buckley, Cynanchum barbigerum (Scheele) Shinners, Dalea scandens, Oenothera brachycarpa A. Gray, Smallanthus maculatus (Cav.) H. Rob., Stevia origanoides Kunth and Tauschia madrensis J.M. Coult. \& Rose (Appendix 1).

The biological forms of the medicinal species mentioned by the interviewees were herbaceous ( 47 species), shrubs (21 species) and trees (17 species).

The most frequently used plant parts for the preparation of medicines were leaves ( 42 plants), branches (leaf and stem) (21 plants), roots (8 plants), whole plants ( 6 plants), flowers (6 plants), fruits ( 5 plants), tree bark (4 plants) (Appendix 1).

\section{Disease categories}

In the region, a total of 50 illnesses or diseases are treated with medicinal plants. Local people choose to use plants, mainly for stomachaches (22 plants), kidney diseases (13 plants), diarrhea (12 plants), coughs (11 plants), spots on skin (9 plants) and others (Appendix 1).

Other medicinal plants in Güémez such as Glandularia bipinnatifida (Schauer) Nutt., Smilax bona-nox L., Cestrum tomentosum L.f., Ruta graveolens, Rosmarinus officinalis L. and Ocimum basilicum L. are used for magical purposes, mainly to remove bad luck and cleanse the soul. 
Use value (UV)

Use values range from 0.008 to 0.44 . The highest values were reported for Artemisa ludoviciana (UV = $0.44)$, Mentha spicata (UV =0.38), Matricaria recutita (UV =0.32), Achillea millefolium $=0.26)$, Marrubium vulgare L. (UV = 0.22), Azadirachta indica A. Juss. (UV = 0.22), Psidium guajava L. (UV = 0.21), Ruta graveolens $(\mathrm{UV}=0.20)$ (Appendix 1).

\section{Informant consensus factor (ICF)}

There were 13 main categories of ailments based on ICF data. The ICF interval was 0.1 to 0.93 . The results showed that the highest ICF was reported for the fever category with a value of 0.93 , followed by ophthalmological problems (mainly eye infections) (0.75), intestinal parasites (mainly worms) (0.75), respiratory ailments (mainly colds) (0.72) and endocrine system (mainly diabetes) (0.66), gastrointestinal system $(0.59)$ and bumps and wounds (0.59) (Table 1$)$.

Table 1. Informant consensus factor (ICF)

\begin{tabular}{|c|c|c|c|c|c|}
\hline $\mathrm{N}^{\circ}$ & Category & Ailments and diseases & $\begin{array}{c}\text { Number } \\
\text { of } \\
\text { citations }\end{array}$ & $\begin{array}{l}\text { Number } \\
\text { of species }\end{array}$ & ICF \\
\hline 1 & $\begin{array}{l}\text { Gastrointestinal } \\
\text { system }\end{array}$ & $\begin{array}{l}\text { Gastritis, bad digestion, constipation, intestinal } \\
\text { ulcers, diarrhea, vomiting, stomach } \\
\text { inflammation, flatulence, nausea, stomach pain, } \\
\text { lack of appetite, toothache, mouth infection, bad } \\
\text { breath }\end{array}$ & 95 & 39 & 0.59 \\
\hline 2 & Respiratory system & Bronchi, asthma, cough & 45 & 13 & 0.72 \\
\hline 3 & Blows and wounds & $\begin{array}{l}\text { External blows, wounds, internal blows, sunken } \\
\text { fontanelle, extraction of thorns }\end{array}$ & 28 & 12 & 0.59 \\
\hline 4 & Dermatological & $\begin{array}{c}\text { Rash, ringworm, herpes virus, baldness, foot } \\
\text { fungus }\end{array}$ & 14 & 16 & 0.15 \\
\hline 5 & Endocrine system & Diabetes, cancer & 25 & 9 & 0.66 \\
\hline 6 & Nervous system & $\begin{array}{l}\text { Insomnia, headache, nervousness, stress, } \\
\text { dizziness }\end{array}$ & 15 & 10 & 0.32 \\
\hline 7 & $\begin{array}{l}\text { Muscular skeletal } \\
\text { system }\end{array}$ & Rheumatism, osteoporosis & 6 & 3 & 0.6 \\
\hline 8 & Circulatory system & $\begin{array}{c}\text { Hemorrhoids, varicose veins, anaemia, impaired } \\
\text { immune system }\end{array}$ & 14 & 7 & 0.53 \\
\hline 9 & Fever & High temperature, typhoid & 16 & 2 & 0.93 \\
\hline 10 & Intestinal parasites & Worms & 9 & 3 & 0.75 \\
\hline 11 & Ophthalmologic & Eye infection & 5 & 2 & 0.75 \\
\hline 12 & Urinary system & Kidney, urinary tract infections & 24 & 13 & 0.47 \\
\hline 13 & $\begin{array}{l}\text { Female reproductive } \\
\text { system }\end{array}$ & Menstrual cramps, infertility, abortion & 10 & 10 & 0.1 \\
\hline
\end{tabular}

\section{Method of preparation of the traditional medicines}

The medicinal plants used by the local inhabitants are prepared and administered in different ways. Various methods of preparation and application are presented. According to ailment, preparation differs such as being boiled ( 62 plants), taken raw (17 plants), fermented in water ( 6 plants), cooked ( 3 plants), fermented in alcohol ( 2 plants), and fried (1 plant) (Appendix 1). Boiled and crude are the most commonly used methods for preparation of remedies. As a result of the records of the interviews, 50 species of plants are prepared for consumption, 15 plants are prepared for external use, while 20 species are used to alleviate both internal and external ailments. 
The main routes of administration of the plants are oral (76\%), followed by intestinal washes $(24 \%)$ and poultices $(4 \%)$. We do not include the exact proportions used for each medicinal plant, because there is a contradiction with respect to the exact dosage. The dose is usually measured by cups of infusion.

Most remedies are based on the use of a plant. However, Table 2 shows eleven combinations of medicinal plants reported by informants. Most are composed of six species, of which Mentha spicata is the plant most used in several combinations, followed by Psidium guajava, Ocimum basilicum, Ruta graveolens, Matricaria recutita and Poliomintha longiflora. The combination of the species Crataegus tracyi and Arctostaphylos pungens is the most recorded one found during the interviews. The main ailments treated with these mixtures are gastrointestinal diseases.

Table 2. Combinations of plant species used for medicinal purposes in Güémez, Tamaulipas, Mexico

\begin{tabular}{|c|c|c|c|c|}
\hline Recipe & Plants and used part & $\begin{array}{l}\text { Ailment/ } \\
\text { Symptoms }\end{array}$ & Preparation & $\begin{array}{c}\text { Number of } \\
\text { mentions }\end{array}$ \\
\hline 1 & $\begin{array}{c}\text { Mentha spicata(leaves), } \\
\text { Quercus polymorpha(treebark), } \\
\text { Rosa gallica(flower) }\end{array}$ & Stomach pain & Boiled, drink solution & 1 \\
\hline 2 & $\begin{array}{c}\text { Psidium guajava (leaves), } \\
\text { Cinnamomum sp. (tree bark), } \\
\text { Majorana hortensis (branch), } \\
\text { Achillea millefolium (leaves) }\end{array}$ & Diarrhea & Boiled, drink solution & 1 \\
\hline 3 & $\begin{array}{c}\text { Crataegus tracyi (root), } \\
\text { Arctostaphylos pungens (root) }\end{array}$ & Kidney & Boiled, drink solution & 6 \\
\hline 4 & $\begin{array}{c}\text { Ocimum basilicum (leaves), } \\
\text { Mentha spicata(leaves) }\end{array}$ & Cough & Boiled, drink solution & 1 \\
\hline 5 & $\begin{array}{l}\text { Agave celsii (leaves), } \\
\text { Citrus limon (fruits) }\end{array}$ & Fever & & 3 \\
\hline 6 & $\begin{array}{c}\text { Mentha spicata (Leaves), } \\
\text { Matricaria recutita (branch), } \\
\text { Ruta graveolens (branch) }\end{array}$ & Stomach pain & Boiled, drink solution & 1 \\
\hline 7 & $\begin{array}{c}\text { Prosopis glandulosa (tree bark), } \\
\text { Ebenopsis ebano (tree bark), } \\
\text { Opuntia spp. (cactus leaves) }\end{array}$ & Diarrhea & Boiled, drink solution & 1 \\
\hline 8 & $\begin{array}{c}\text { Eucalyptus globulus (leaves), } \\
\text { Poliomintha longiflora (leaves) }\end{array}$ & Cough & Boiled, drink solution & 1 \\
\hline 9 & $\begin{array}{c}\text { Ocimum basilicum (leaves), } \\
\text { Poliomintha longiflora (branch) }\end{array}$ & Stomach pain & Boiled, drink solution & 1 \\
\hline 10 & $\begin{array}{l}\text { Psidium guajava (leaves), } \\
\text { Prunus persica (leaves) }\end{array}$ & Stomach pain & Boiled, drink solution & 1 \\
\hline 11 & $\begin{array}{c}\text { Cynodon dactylon (whole plant), } \\
\text { Matricaria recutita (branch), } \\
\text { Ruta graveolens (branch) }\end{array}$ & Digestion & $\begin{array}{l}\text { Mix these plants, apply some } \\
\text { heat, place on a flannel with } \\
\text { ashes and pieces of brick, put } \\
\text { over the stomach }\end{array}$ & 1 \\
\hline
\end{tabular}

\section{Discussion}

The Asteraceae family has been reported as the most used in several regions of Mexico (Cervantes and Valdés, 1990; Camou-Guerrero et al., 2008; Alonso-Castro et al., 2012; Estrada-Castillón et al., 2014, 2018; García-Hernández et al., 2015; Pérez-Nicolás et al., 2017; Esquivel-García et al., 2018), as well as worldwide (Ghorbani et al., 2011; Bulut and Tuzlaci, 2013; Leto et al., 2013; Nawash et al., 2013; Bolson et al., 2015), probably due to the high diversity of its phytochemical constituents. Some studies have reported that this family 
has a wide range of biologically active compounds and has high species richness worldwide (Heinrich et al., 1998; Thomas et al., 2009).

Following the IUCN Red List of Threatened Species, the only species under protection status is Dalea scandens (Mill.) R.T. Clausen assessed as being of Least Concern (Groom, 2012).

The possible reasons that herbaceous plants have the highest frequency of use is because bioactive compounds can be easily extracted (Lulekal et al., 2013; Kayani et al., 2015) and their high availability (planted in gardens, wild habitat and roadsides) (Tsobou et al., 2013). Similar conclusions are drawn from other studies in other parts of the world (Ghorbani et al., 2011; Sivasankari et al., 2014; Yaseen et al., 2015).

The medicinal species best known by the population in the study area were those that were used for uncomplicated ailments, similar findings are reported by Pérez-Nicolás et al. (2017) for the state of Oaxaca in southeaster Mexico.

The most frequently used plant parts for the preparation of medicines were leaves. Several ethnomedicinal studies in Mexico, Bangladesh, China, Colombia and India have reported that leaves are the most used parts of plants (Singh and Singh, 2009; Teklehaymanot, 2009; Packer et al., 2012; Sivasankari et al., 2014; Pérez-Nicolás et al., 2017; Estrada-Castillón et al., 2018). This is because they are the most abundant part of a plant and they are easier to collect (Giday et al., 2003). It may also be due to their greater effectiveness, since leaves have increased amounts of secondary metabolites like alkaloids, tannins and inulins, which are active components of many medicines (Yemele et al., 2015). In addition, the use of leaves favors the conservation of plants, since the collection of roots can kill the plant and endanger the species (Telefo et al., 2012; Kadir et al., 2013).

In the study area the most frequently used medicinal species are Artemisia ludoviciana, Mentha spicata, Matricaria recutita and Ruta graveolens, in the same way such plants are used by the inhabitants of Santiago Camotlán, Oaxaca (Pérez-Nicolás et al., 2017).

\section{Disease categories}

Ethnobotanical studies reveal that stomach pain is the most frequent ailment treated by medicinal plants (Polat and Satil, 2012; Kayani et al., 2015; Tribess et al., 2015; Estrada-Castillón et al., 2018). Globally, gastrointestinal diseases account for 2.2 million deaths each year and are caused by viruses, bacteria or parasites (Monigatti et al., 2013). The second most notable illness was related to the kidneys, which may be due to low intake of water during the cold season and the hard-agricultural work (Kayani et al., 2015).

In the study area medicinal plants are also used for magical purposes, like to remove bad luck. This is a common practice in the Mexican tradition (Frei et al., 1998; Andrade-Cetto, 2009). Since ancient times in Mexico, people have believed that diseases were caused by evil spirits, witchcraft and magic (Gallardo-Arias, 2004). Local healers prescribe medicinal plants, through a ritual of prayers while rubbing medicinal plants on the body of sick person. Most informants mentioned that such traditional knowledge was transmitted by their parents and grandparents over the years.

\section{Use Value (UV) and Informant Consensus Factor (ICF)}

Most of the plant's species registered in this study are native to Europe and Asia and their use may have been popularized in Mexico because of their efficiency, adaptation and fast growth (Juárez-Rosete et al., 2013).

The high values of ICF could indicate that these diseases are common in the studied population, where there is a need to cure these diseases, and, thus, there is knowledge among the local population about the uses of medicinal plants (Nawash et al., 2013).

\section{Method of preparation of the traditional medicines}

Oral is the most routes of administration of plants used by the inhabitants of this study area because of their ease, similar findings have been reported in countries such as Pakistan (Kadir et al., 2012, 2013) and India (Ayyanar and Ignacimuthu, 2011). 
Most remedies are based on the use of a plant and other is combinations of medicinal plants reported by informants. This can be attributed to the fact that any one plant can contain several compounds that perform different functions in the body (Focho et al., 2009). The plants are combined because people believe that the blend could improve the synergistic effect of the pharmacological effects of plants (Igoli et al., 2005; Giday et al., 2010).

\section{Conclusions}

This study reveals that for the inhabitants of the municipality of Güémez, the use of traditional medicine is frequent, and most local people still rely on plant-based remedies for common health problems. Thus, we emphasize the need to develop actions to avoid the loss of traditional knowledge of medicinal plants, not only to preserve this cultural heritage but also to record information on useful species that could be used to develop new medicines and provide other benefits, while contributing to protecting local biodiversity.

\section{Authors' Contributions}

Conceptualization: EEC and SNJG; Data curation: SNJG and JRAS; Funding acquisition: EEC, Investigation: SNJG and JAED; Methodology: EEC, SNJG and JAVQ; Project administration: JRAS and EEC; Supervision: JAVQ and JAED; Writing - original draft: SNJG; Writing - review and editing: JAED. All authors read and approved the final manuscript. All authors read and approved the final manuscript.

\section{Acknowledgements}

We are very grateful to the residents of the municipality of Güémez for sharing their knowledge about medicinal plants, as well as the staff of the FCNL-Herbarium for their assistance during identification. Thanks to Omar Rueda Moreno for preparing Figure 1. We thank the PAICYT (Support Program for Scientific and Technological Research) of the Universidad Autónoma de Nuevo León for the economic support to carry out this study.

\section{Conflict of Interests}

The authors declare that there are no conflicts of interest related to this article.

\section{References}

Alonso-Castro A, Maldonado-Miranda J, Zarate-Martínez A, Jacobo-Salcedo M, Fernández-Galicia C, Figueroa-Zúñiga L, ... Carranza-Álvarez C (2012). Medicinal plants used in the Huasteca Potosina, México. Journal of Ethnopharmacology 143:292-298. https://doi.org/10.1016/j.jep.2012.06.035

Andrade-Cetto A (2009). Ethnobotanical study of the medicinal plants from Tlanchinol, Hidalgo, México. Journal of Ethnopharmacology 122:163-171. https://doi.org/10.1016/j.jep.2008.12.008

Ayyanar M, Ignacimuthu S (2011). Ethnobotanical survey of medicinal plants commonly used by Kanitribals in Tirunelveli hills of western Ghats, India. Journal of Ethnopharmacology 134:851-864. https://doi.org/10.1016/j.jep.2011.01.029 
Bermúdez A, Oliveira-Miranda MA, Velázquez D (2005). La investigación etnobotánica sobre plantas medicinales: una revisión de sus objetivos y enfoques actuales [Ethnobotanical research on medicinal plants: a review of their current objectives and approaches]. Interciencia 30:453-459. http://www.saber.ula.ve/handle/123456789/16618

Bolson M, Hefler S, Dall'Oglio E, Gasparotto A, Cardozo E (2015). Ethno-medicinal study of plants used for treatment of human ailments, with residents of the surrounding region of forest fragments of Paraná, Brazil. Journal of Ethnopharmacology 161:1-10. https://doi.org/10.1016/j.jep.2014.11.045

Bulut G, Tuzlaci E (2013). Ethnobotanical study of medicinal plants in Turgutlu (Manisa-Turkey). Journal of Ethopharmacology 149:633-647. https://doi.org/10.1016/j.jep.2013.07.016

Calvo MI, Akerreta S, Cavero RY (2011). Pharmaceutical ethnobotany in the Riverside of Navarra (Iberian Peninsula). Journal of Ethnopharmacology 135(1):22-33. https://doi.org/10.1016/j.jep.2011.02.016

Camou-Guerrero A, Reyes-García V, Martínez-Ramos M, Casas A (2008). Knowledge and use value of plant species in a rarámuri community: A gender perspective for conservation. Human Ecology 36:259-272. https://doi.org/10.1007/s10745-007-9152-3

Cano JH, Volpato G (2004). Herbal mixtures in the traditional medicine of eastern Cuba. Journal of Ethnopharmacology 90:293-316. https://doi.org/10.1016/j.jep.2003.10.012

Casas A, Valiente-Banuet A, Viveros J, Caballero J, Cortés L, Dávila P, Lira R, Rodríguez I (2001). Plant resources of the Tehuacan-Cuicatlan Valley, Mexico. Economic Botany 55:129-166. https://doi.org/10.1007/BF02864551

Cervantes L, Valdés J (1990). Plantas medicinales del Distrito de Ocotlán Oaxaca [Medicinal plants of the District of Ocotlán Oaxaca]. Anales Instituto de Biología Universidad Nacional Autónoma de México. Serie Botánica 60:85103.

Correll DS, Johnston MC (1970). Manual of the vascular plants of Texas. University of Texas, Dallas, TX.

Esquivel-García R, Pérez-Calix E, Ochoa-Zarzosa A, García-Pérez ME (2018). Ethnomedicinal plants used for the treatment of dermatological affections on the Purépecha Plateau, Michoacán, Mexico. Acta Botanica Mexicana 125:95-132. http://dx.doi.org/10.21829/abm125.2018.1339

Estrada-Castillón E, Garza-López M, Villarreal-Quintanilla JA, Salinas-Rodríguez M, Soto-Mata B, González-Rodríguez H, ... Cantú-Ayala C (2014). Ethnobotany in Rayones, Nuevo León, México. Journal of Ethnobiology and Ethnomedicine 10:1-13. https://doi.org/10.1186/1746-4269-10-62

Estrada-Castillón E, Villarreal-Quintanilla JA, Salinas-Rodríguez M, Encina-Domínguez JA, González-Rodríguez H, Romero Figueroa G, Arévalo JR (2018). Ethnobotanical survey of useful species in Bustamante, Nuevo León, Mexico. Human Ecology 46:117-132. https://doi.org/10.1007/s10745-017-9962-X

Focho DA, Nkeng EAP, Lucha CF, Ndam WT, Afegenu IA (2009). Ethnobotanical survey of plants used to treat diseases of the reproductive system and preliminary phytochemical screening of some species of Malvaceae in Ndop central sub-division, Cameroon. Journal of Medicinal Plants Research 3:301-314.

Frei B, Baltisberger M, Sticher O, Heinrich M (1998). Medical ethnobotany of the Zapotecs of the Isthmus-Sierra (Oaxaca, Mexico): documentation and assessment of indigenous uses. Journal of Ethnopharmacology 62:149-165. https://doi.org/10.1016/S0378-8741(98)00051-8

Gallardo-Arias P (2004). Los especialistas de la curación. Curanderos teenek y nahuas de Aquismón [The healing specialists. Teenek and Nahuas healers of Aquismón]. Anales de Antropología 38:179-200. http://dx.doi.org/10.22201/iia.24486221e.2004.1.16589

García-Hernández K, Vibrans H, Rivas-Guevara M, Aguilar-Contreras A (2015). This plant treats that illness? The hotcold system and therapeutic procedures mediate medicinal plant use in San Miguel Tulancingo, Oaxaca, Mexico. Journal of Ethnopharmacology 163:12-30. https://doi.org/10.1016/j.jep.2015.01.001

Ghorbani A, Langenberger G, Feng L, Sauerborn J (2011). Ethnobotanical study of medicinal plants utilized by Hani ethnicity in Naban river watershed national nature reserve, Yunnan, China. Journal of Ethnopharmacology 134:651-667. https://doi.org/10.1016/j.jep.2011.01.011

Giday M, Asfaw Z, Elmqvist T, Woldu Z (2003). An ethnobotanical study of medicinal plants used by the Zay people in Ethiopia. Journal of Ethnopharmacology 85:43-52. https://doi.org/10.1016/S0378-8741(02)00359-8

Giday M, Asfaw Z, Woldu Z (2010). Ethnomedicinal study of plants used by Sheko ethnic group of Ethiopia. Journal of Ethnopharmacology 132:75-85. https://doi.org/10.1016/j.jep.2010.07.046

Gómez AR (2012). Plantas medicinales en una aldea del Estado de Tabasco, México [Medicinal plants in a village in the State of Tabasco, Mexico]. Revista Fitotecnia Mexicana 35:43-49.

Groom A (2012). Dalea scandens. The IUCN Red List of Threatened Species 2012. https://doi.org/10.2305/IUCN.UK.2012 
Hassan-Abdallah A, Merito A, Hassan S, Aboubaker D, Djamab M, Asfaw Z, Kelbessa E (2013). Medicinal plants and their uses by the people in the region of Randa, Djibouti. Journal of Ethnopharmacology 148:701-713. https://doi.org/10.1016/j.jep.2013.05.033

Heinrich M, Robles M, West JE, Ortiz de Montellano BR, Rodríguez E (1998). Ethnopharmacology of mexican Asteraceae (Compositae). Annual Review of Pharmacology and Toxicology 38:539-565. https://doi.org/10.1146/annurev.pharmtox.38.1.539

Igoli JO, Ogali OJ, Tor-Anyiin TA, Igoli NP (2005). Traditional medicine practice amongst the Igede people of Nigeria. Part II. African Journal of Traditional Complementary and Alternative Medicines 2:134-152.

INEGI (Instituto Nacional de Estadística y Geografía). (2009). Prontuario de información geográfica municipal de los Estados Unidos Mexicanos, México [Municipal geographic information record of the United Mexican States, Mexico].

Juárez-Rosete CR, Aguilar-Castillo JA, Juárez-Rosete ME, Bugarín-Montoya R, Juárez-López P (2013). Hierbas aromáticas y medicinales en México: tradición e innovación [Aromatic and medicinal herbs in Mexico: tradition and innovation]. Revista Biociencias 2:119-129. https://doi.org/10.15741/revbio.02.03.06

Kadir M, Bin M, Shams T, Mia MMK (2012). Ethnobotanical survey of medicinal plants used by Bangladeshi traditional health practitioners in the management of diabetes mellitus. Journal of Ethnopharmacology 144:605-611. https://doi.org/10.1016/j.jep.2012.09.050

Kadir M, Bin M, Shams T, Mia MMK (2013). Ethnopharmacological survey of medicinal plants used by traditional healers in Bangladesh for gastrointestinal disorders. Journal of Ethnopharmacology 147:148-156. https://doi.org/10.1016/j.jep.2013.02.023

Kayani S, Ahmad M, Sultana S, Shinwari Z, Zafar M, Yaseen G, ... Bibi T (2015). Ethnobotany of medicinal plants among the communities of Alpine and Sub-alpine regions of Pakistan. Journal of Ethnopharmacology 164:186-202. https://doi.org/10.1016/j.jep.2015.02.004

Leto C, Tuttolomondo T, La Bella S, Licata M (2013). Ethnobotanical study in the Madonie Regional Park (Central Sicily, Italy)-Medicinal use of wild shrub and herbaceous plant species. Journal of Ethnopharmacology 146:90112. https://doi.org/10.1016/j.jep.2012.11.042

Lulekal E, Asfaw Z, Kelbessa E, Van Damme P (2013). Ethnomedicinal study of plants used for human ailments in Ankober District, North Shewa Zone, Amhara region, Ethiopia. Journal of Ethnobiology and Ethnomedicine 9:113. https://doi.org/10.1186/1746-4269-9-63

Malla B, Gauchan D, Chhetri R (2015). An ethnobotanical study of medicinal plants used by ethnic people in Parbat district of western Nepal. Journal of Ethnopharmacology 165:103-117. https://doi.org/10.1016/j.jep.2014.12.057

Mercado A (2013). Estudio de plantas medicinales usadas por cuicatecos en la localidad de Santos Reyes Pápalo, Cuicatlán, Oaxaca. [Study of medicinal plants used by cuicatecos in Santos Reyes Pápalo, Cuicatlán, Oaxaca.] Unpublished Bachelor's Thesis. Universidad Nacional Autónoma de México. México, D.F.

Monigatti M, Bussmann R, Weckerle C (2013). Medicinal plant use in two Andean communities located at different altitudes in the Bolívar Province, Peru. Journal of Ethnopharmacology 145:450-464. https://doi.org/10.1016/j.jep.2012.10.066

Nawash O, Shudiefat M, Al-Tabini R, Al-Khalidi K (2013). Ethnobotanical study of medicinal plants commonly used by local bedouins in the Badia region of Jordan. Journal of Ethnopharmacology 148:921-925. https://doi.org/10.1016/j.jep.2013.05.044

Packer J, Brouwer N, Harrington D, Gaikwad J, Heron R, Elders Y, ... Jamie J (2012). An ethnobotanical study of medicinal plants used by the Yaegl Aboriginal community in northern New South Wales, Australia. Journal of Ethnopharmacology 139:244-255._https://doi.org/10.1016/j.jep.2011.11.008

Panyaphu K, Van-On T, Sirisa-ard P, Srisanga P, Chansakaow S, Nathakarnkitkul S (2011). Medicinal plants of the Mien (Yao) in northern Thailand and their potential value in the primary healthcare of postpartum women. Journal of Ethnopharmacology 135:226-237. https://doi.org/10.1016/j.jep.2011.03.050

Pérez-Nicolás M, Vibrans H, Romero-Manzanares A, Saynes-Vásquez A, Luna-Cavazos M, Flores-Cruz M, Lira-Saade R (2017). Patterns of Knowledge and Use of Medicinal Plants in Santiago Camotlán, Oaxaca, Mexico. Economic Botany 71(3):209-223. https://doi.org/10.1007/s12231-017-9384-0

Polat R, Satıl F (2012). An ethnobotanical survey of medicinal plants in Edremit gulf (Balikesir-Turkey). Journal of Ethnopharmacology 139:626-641. https://doi.org/10.1016/j.jep.2011.12.004

Quesada HA (2008). Las plantas medicinales [Medicinal plants]. Revista Biocenosis 21:20-24. 
Sánchez-González A, González LM (2007). Técnicas de recolecta de plantas y herborización. In: Contreras-Ramos A, Cuevas-Cardona C, Goyenechea I, Iturbide U. La sistemática, base del conocimiento de la biodiversidad [Plant collection techniques and herbization] pp 123-133. Universidad Autónoma del Estado de Hidalgo, Hidalgo, México.

Singh A, Singh PK (2009). An ethnobotanical study of medicinal plants in Chandauli District of Uttar Pradesh, India. Journal of Ethnopharmacology 121:324-329. https://doi.org/10.1016/j.jep.2008.10.018

Sivasankari B, Amamdharaj M, Gunasekaran P (2014). An ethnobotanical study of indigenous knowledge on medicinal plants used by the village peoples of Thoppampatti, Dindigul district, Tamilnadu, India. Journal of Ethnopharmacology 153:408-423. https://doi.org/10.1016/j.jep.2014.02.040

Teklehaymanot T (2009). Ethnobotanical study of knowledge and medicinal plants use by the people in Dek Island in Ethiopia. Journal of Ethnopharmacology 124:69-78. https://doi.org/10.1016/j.jep.2009.04.005

Telefo PB, Lemfack MC, Bayala B, Lienou LL, Goka CS, Yemele CD, ... Moundipa FP (2012). Enquête ethnopharmacologique des plantes utilisées dans le traitement de l'infertilité féminine dans les localités de FossongWentcheng et Foto, Cameroun [Ethnopharmacological survey of plants used in the treatment of female infertility in the localities of Fossong-Wentcheng and Foto, Cameroon]. Phytotherapie 10:25-34. https://doi.org/10.1007/s10298-011-0678-6

Thiers B (2016). Index Herbariorum: A global directory of public herbaria and associated staff. New York Botanical Garden's Virtual Herbarium. Retrieved 2020 April 15 from: http://sweetgum.nybg.org/science/ih/

Thomas E, Vandebroek I, Sanca S, Van Damme P (2009). Cultural significance of medicinal plant families and species among the Quechua farmers in Apillapampa, Bolivia. Journal of Ethnopharmacology 112:60-67. https://doi.org/10.1016/j.jep.2008.11.021

Tribess B, Melatto G, Alida L, Camargo A, Funez L, Gasper A, Bertarello A (2015). Ethnobotanical study of plants used for therapeutic purposes in the Atlantic Forest region, Southern Brazil. Journal of Ethnopharmacology 164:136146. https://doi.org/10.1016/j.jep.2015.02.005

Trotter RT, Logan MH (1986). Informant census: A new approach for identifying potentially effective medicinal plants. In: Etkin LN (Ed.), Plants in indigenous medicine and diet. Redgrave, Bedford Hill, New York.

Tsobou R, Mapongmetsemm PM, Van Damme PM (2013). Medicinal plants used against typhoid fever in Bamboutos division, western Cameroon. Ethnobotany Research \& Applications 11:163-174.

Yaseen G, Ahmad M, Sultana S, Alharrasi A, Hussain J, Zafar M, Ur-Rehman S (2015). Ethnobotany of medicinal plants in the Thar Desert (Sindh) of Pakistan. Journal of Ethnopharmacology 163:43-59. https://doi.org/10.1016/j.jep.2014.12.053

Yemele MD, Telefo PB, Lieneou LL, Tagne SR, Fodouop CSP, Gpka CS, Lemfack MC, Moundipa FP (2015). Ethnobotanical survey of medicinal plants used for pregnant women's health conditions in Menoua division-west Cameroon. Journal of Ethnopharmacology 160:14-31. https://doi.org/10.1016/j.jep.2014.11.017

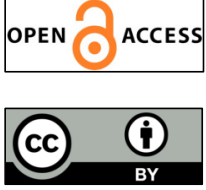

The journal offers free, immediate, and unrestricted access to peer-reviewed research and scholarly work. Users are allowed to read, download, copy, distribute, print, search, or link to the full texts of the articles, or use them for any other lawful purpose, without asking prior permission from the publisher or the author.

License - Articles published in Notulae Botanicae Horti Agrobotanici Cluj-Napoca are Open-Access, distributed under the terms and conditions of the Creative Commons Attribution (CC BY 4.0) License. (C) Articles by the authors; UASVM, Cluj-Napoca, Romania. The journal allows the author(s) to hold the copyright/to retain publishing rights without restriction. 


\section{Supplementary files}

Appendix 1. List of species used in traditional medicine in Güémez, Tamaulipas, Mexico. Specimens herbarium collected by Sindi J. Gandara (SJG)

\begin{tabular}{|c|c|c|c|c|c|c|}
\hline $\begin{array}{c}\text { Family / } \\
\text { Scientific name }\end{array}$ & $\begin{array}{l}\text { Common } \\
\text { name }\end{array}$ & Uses & Part used & Method of use & $\begin{array}{c}\text { Numbers } \\
\text { of use } \\
\text { reports }\end{array}$ & $\begin{array}{c}\text { Use } \\
\text { Value } \\
\text { (UV) } \\
\end{array}$ \\
\hline \multicolumn{7}{|l|}{ Amaranthaceae } \\
\hline $\begin{array}{l}\text { Amaranthus } \\
\text { palmeriS. } \\
\text { Watson } \\
\text { (SJG 034) } \\
\end{array}$ & Quelite & Prevention osteoporosis & Leaves & Cooked and eat & 1 & 0.008 \\
\hline \multirow[t]{3}{*}{$\begin{array}{l}\text { Chenopodium } \\
\text { ambrosioides } \mathrm{L} \text {. } \\
\text { (SJG 041) }\end{array}$} & Epazote & Menstrual colic & Leaves & Boiled, drink solution & 10 & 0.08 \\
\hline & & Stomach ache & Leaves & Boiled, drink solution & & \\
\hline & & Intestinal parasites & Leaves & Boiled, drink before breakfast & & \\
\hline \multicolumn{7}{|l|}{ Anacardiaceae } \\
\hline $\begin{array}{c}\text { Rhus virens } \\
\text { Lindh. ex. A. } \\
\text { Gray (SJG 67) }\end{array}$ & Lantrisco & Diabetes & Leaves & Boiled, drink solution & 7 & 0.06 \\
\hline \multicolumn{7}{|l|}{ Apiaceae } \\
\hline $\begin{array}{c}\text { Tauschia } \\
\text { madrensis J.M. } \\
\text { Coult. \& Rose } \\
\text { (SJG 0126) }\end{array}$ & Acocotillo & Cough & Leaves & Boiled, drink solution & 1 & 0.008 \\
\hline \multicolumn{7}{|l|}{ Apocynaceae } \\
\hline $\begin{array}{c}\text { Cynanchum } \\
\text { barbigerum } \\
\text { (Scheele) } \\
\text { Shinners (SJG } \\
\text { 0115). }\end{array}$ & $\begin{array}{l}\text { Pico de } \\
\text { pájaro }\end{array}$ & Kidney diseases & Root & Boiled, drink solution & 1 & 0.008 \\
\hline \multicolumn{7}{|l|}{ Asparagaceae } \\
\hline \multirow[t]{5}{*}{$\begin{array}{c}\text { Agave celsii } \\
\text { Hook. (SJG } \\
0120) \\
\end{array}$} & $\begin{array}{l}\text { Maguey de } \\
\text { peña }\end{array}$ & Diarrhea & Leaves & Roasted, squeeze and drink juice & 11 & 0.09 \\
\hline & & Headache & Leaves & Roasted, squeeze and drink juice & & \\
\hline & & Fever & Leaves & Roasted, squeeze and drink juice & & \\
\hline & & Internal pains & Leaves & Roasted, squeeze and drink juice & & \\
\hline & & Vomit & Leaves & Roasted, squeeze and drink juice & & \\
\hline $\begin{array}{c}\text { Agave } \\
\text { lechuguilla Torr. } \\
\text { (SJG 0121) }\end{array}$ & Lechuguilla & Kidney diseases & Root & Fermented in water, drink solution & 2 & 0.01 \\
\hline \multicolumn{7}{|l|}{ Asphodelaceae } \\
\hline \multirow[t]{6}{*}{$\begin{array}{c}\text { Aloe vera (L.) } \\
\text { Burm. f. } \\
\text { (SJG 0121) }\end{array}$} & Sábila & External wounds & Leaves & Poultice on wound & 12 & 0.1 \\
\hline & & Hair loss & Leaves & Cataplasm on hair & & \\
\hline & & $\begin{array}{l}\text { Anti-inflammatory for } \\
\text { stomach }\end{array}$ & Leaves & Eating raw pieces & & \\
\hline & & Rheumatism & Leaves & Cataplasm on affected area & & \\
\hline & & Gastritis & Leaves & Eating raw pieces & & \\
\hline & & External pains or injuries & Leaves & Cataplasm on affected area & & \\
\hline \multicolumn{7}{|l|}{ Asteraceae } \\
\hline \multirow[t]{3}{*}{$\begin{array}{c}\text { Achillea } \\
\text { millefolium L. } \\
\text { (SJG 016) }\end{array}$} & Real de oro & Toothache & Leaves & Boiled, mouthwash & 30 & 0.26 \\
\hline & & Stomach ache & Leaves & Boiled, drink solution & & \\
\hline & & Vomit & Leaves & Boiled, drink solution & & \\
\hline $\begin{array}{c}\text { Ambrosia } \\
\text { confertiflora } \\
\text { DC. (SJG 047) }\end{array}$ & Altamisa & Anti-inflammatory stomach & Branch & Boiled, drink solution & 2 & 0.01 \\
\hline
\end{tabular}


Jasso-Gándara SN et al. (2020). Not Bot Horti Agrobo 48(3):1130-1140

\begin{tabular}{|c|c|c|c|c|c|c|}
\hline $\begin{array}{c}\text { Family / } \\
\text { Scientific name }\end{array}$ & $\begin{array}{l}\text { Common } \\
\text { name }\end{array}$ & Uses & Part used & Method of use & $\begin{array}{c}\begin{array}{c}\text { Numbers } \\
\text { of use } \\
\text { reports }\end{array} \\
\end{array}$ & $\begin{array}{c}\text { Use } \\
\text { Value } \\
\text { (UV) }\end{array}$ \\
\hline & & Hemorrhoids & Stems and leaves & $\begin{array}{l}\text { Moisten and rub on the affected } \\
\text { area }\end{array}$ & & \\
\hline \multirow[t]{2}{*}{$\begin{array}{c}\text { Artemisia } \\
\text { Iudoviciana } \\
\text { Nutt. (SJG 044) }\end{array}$} & Estafíate & Diarrhea & Leaves & Boiled, drink solution & 51 & 0.44 \\
\hline & & Stomach ache & Leaves & Boiled, drink solution & & \\
\hline $\begin{array}{l}\text { Bidens pilosa L. } \\
\text { (SJG 069) }\end{array}$ & Pícaro & Kidney diseases & Stems and leaves & Boiled, drink solution & 1 & 0.008 \\
\hline \multirow[t]{3}{*}{$\begin{array}{c}\text { Calyptocarpus } \\
\text { vialis Less. } \\
\text { (SJG 025) }\end{array}$} & $\begin{array}{l}\text { Hierba de la } \\
\text { hormiga }\end{array}$ & Rash & Stems and leaves & Boiled, wash affected area & 1 & 0.008 \\
\hline & & External pains & Stems and leaves & Boiled, wash affected area & & \\
\hline & & External wounds & Stems and leaves & Boiled, wash affected area & & \\
\hline $\begin{array}{c}\text { Cirsium } \\
\text { texanum } \\
\text { Buckley } \\
\text { (SJG 0123) }\end{array}$ & Escobilla & Abortive & Leaves and flower & Boiled, drink solution & 1 & 0.008 \\
\hline \multirow[t]{10}{*}{$\begin{array}{c}\text { Matricaria } \\
\text { recutita } \mathrm{L} . \\
(\mathrm{SJG} 07)\end{array}$} & Manzanilla & Menstrual colic & Stems, leaves and flower & Boiled, drink solution & 37 & 0.32 \\
\hline & & Headache & Stems, leaves and flower & Boiled, drink solution & & \\
\hline & & Stomach ache & Stems, leaves and flower & Boiled, drink solution & & \\
\hline & & External wounds & Stems, leaves and flower & Boiled, wash affected area & & \\
\hline & & Flatulence & Stems, leaves and flower & Boiled, drink solution & & \\
\hline & & Eye Infection & Stems, leaves and flower & $\begin{array}{c}\text { Boiled, make compresses and place } \\
\text { on eye }\end{array}$ & & \\
\hline & & Queasiness & Stems, leaves and flower & Boiled, drink solution & & \\
\hline & & Dizziness & Stems, leaves and flower & Boiled, drink solution & & \\
\hline & & Cough & Stems, leaves and flower & Boiled, drink solution & & \\
\hline & & Diarrhea & & Boiled, drink solution & & \\
\hline $\begin{array}{c}\text { Parthenium } \\
\text { hysterophorus } \mathrm{L} . \\
\text { (SJG 075) }\end{array}$ & Amargoso & Gastritis & Stems and leaves & Moisten, squeeze and drink solution & 4 & 0.03 \\
\hline \multirow[t]{3}{*}{$\begin{array}{c}\text { Senecio } \\
\text { confusus Britten } \\
\text { (SJG 0104) }\end{array}$} & Árnica & External wounds & Leaves and flower & Boiled, wash & 23 & 0.2 \\
\hline & & Gastritis & Leaves and flower & Boiled, drink solution & & \\
\hline & & Rash & Leaves and flower & Boiled, wash & & \\
\hline $\begin{array}{c}\text { Smallanthus } \\
\text { maculatus } \\
\text { (Cav.) H. Rob. } \\
\text { (SJG 0124) }\end{array}$ & Capitana & External wounds & Leaves & Boiled, wash & 1 & 0.008 \\
\hline $\begin{array}{c}\text { Stevia } \\
\text { origanoides } \\
\text { Kunth } \\
\text { (SJG 068) } \\
\end{array}$ & $\begin{array}{l}\text { Hierba de la } \\
\text { mula }\end{array}$ & Rheumatism & Leaves & $\begin{array}{l}\text { Fermented in alcohol, put in the } \\
\text { affected area }\end{array}$ & 1 & 0.008 \\
\hline $\begin{array}{l}\text { Tagetes erecta } \mathrm{L} . \\
(\mathrm{SJG} 0101)\end{array}$ & Cempasúchil & Stomach ache & Flower & Boiled, drink solution & 2 & 0.01 \\
\hline $\begin{array}{l}\text { Tagetes lucida } \\
\text { Cav. (SJG 015) } \\
\end{array}$ & Hierbanís & Nervousness & Stems, leaves and flower & Boiled, drink solution & 4 & 0.03 \\
\hline $\begin{array}{c}\text { Tagetes } \\
\text { micrantha Cav. } \\
\text { (SJG 029) } \\
\end{array}$ & Anís & Menstrual colic & Stems, leaves and flower & Boiled, drink solution & 1 & 0.008 \\
\hline \multirow[t]{3}{*}{$\begin{array}{c}\text { Tanacetum } \\
\text { parthenium (L.) } \\
\text { Sch. Bip. } \\
\text { (SJG 012) }\end{array}$} & Altamis & Diabetes & Leaves & Boiled, drink solution & 5 & 0.04 \\
\hline & & Stomach ache & Leaves & Boiled, drink solution & & \\
\hline & & Hemorrhoids & Leaves & Boiled, wash & & \\
\hline
\end{tabular}


Jasso-Gándara SN et al. (2020). Not Bot Horti Agrobo 48(3):1130-1140

\begin{tabular}{|c|c|c|c|c|c|c|}
\hline $\begin{array}{c}\text { Family / } \\
\text { Scientific name }\end{array}$ & $\begin{array}{c}\text { Common } \\
\text { name }\end{array}$ & Uses & Part used & Method of use & \begin{tabular}{|c|}
$\begin{array}{c}\text { Numbers } \\
\text { of use } \\
\text { reports }\end{array}$ \\
\end{tabular} & \begin{tabular}{|c|} 
Use \\
Value \\
(UV)
\end{tabular} \\
\hline \multicolumn{7}{|l|}{ Bignoniaceae } \\
\hline $\begin{array}{l}\text { Crescentia alata } \\
\text { Kunth } \\
\text { (SJG 0111) }\end{array}$ & Guajecirial & Bronchia & Fruit & $\begin{array}{c}\text { Open the fruit, put some honey and } \\
\text { leave to ferment, eat only internal } \\
\text { part }\end{array}$ & 1 & 0.008 \\
\hline \multicolumn{7}{|l|}{ Boraginaceae } \\
\hline $\begin{array}{l}\text { Cordia boissieri } \\
\text { A. DC. } \\
\text { (SJG 091) }\end{array}$ & Anacahuita & Cough & Fruit & Boiled, drink solution & 5 & 0.04 \\
\hline \multicolumn{7}{|l|}{ Burseraceae } \\
\hline $\begin{array}{c}\text { Bursera } \\
\text { fagaroides } \\
\text { (Kunth) Engl. } \\
\text { (SJG 092) }\end{array}$ & Salsafras & Diabetes & Leaves & Boiled, drink solution & 2 & 0.01 \\
\hline \multicolumn{7}{|l|}{ Equisetaceae } \\
\hline $\begin{array}{l}\text { Equisetum } \\
\text { hyemale L. } \\
\text { (SJG 060) }\end{array}$ & $\begin{array}{l}\text { Cola de } \\
\text { caballo }\end{array}$ & Kidney diseases & Root & Boiled, drink daily as infusion & 4 & 0.03 \\
\hline \multicolumn{7}{|l|}{ Ericaceae } \\
\hline $\begin{array}{l}\text { Arctostaphylos } \\
\text { pungens Kunth } \\
\text { (SJG 072) }\end{array}$ & Pingüica & Kidney diseases & Root & Fermented in water, drink solution & 13 & 0.11 \\
\hline \multicolumn{7}{|l|}{ Euphorbiaceae } \\
\hline \multirow[t]{5}{*}{$\begin{array}{l}\text { Acalypha } \\
\text { lindheimeri } \\
\text { Müll. Arg. } \\
\text { (SJG 02) }\end{array}$} & $\begin{array}{l}\text { Hierba del } \\
\text { cáncer }\end{array}$ & Prevent cancer & Leaves and flower & Boiled, drink solution & 5 & 0.04 \\
\hline & & External pains & Leaves and flower & Boiled, wash & & \\
\hline & & External wounds & Leaves and flower & Boiled, wash & & \\
\hline & & Rash & Leaves and flower & Boiled, wash & & \\
\hline & & Stomach ache & Leaves and flower & Boiled, drink solution & & \\
\hline $\begin{array}{l}\text { Cnidoscolus } \\
\text { aconitifolius } \\
\text { (Mill.) I.M. } \\
\text { Johnst. } \\
\text { (SJG 088) }\end{array}$ & Chaya & Gastritis & Leaves & Macerated in water, drink solution & 3 & 0.02 \\
\hline $\begin{array}{l}\text { Cnidoscolus } \\
\text { texanus (Müll. } \\
\text { Arg.) small } \\
\text { (SJG 081) }\end{array}$ & Mano santa & Kidney diseases & Leaves & Boiled, drink solution & 1 & 0.008 \\
\hline $\begin{array}{c}\text { Croton incanus } \\
\text { Kunth } \\
\text { (SJG 051) }\end{array}$ & Palillo & Ringworm & Leaves & Macerated, put on the affected area & 1 & 0.008 \\
\hline \multirow[t]{3}{*}{$\begin{array}{c}\text { Croton } \\
\text { suaveolens } \text { Torr. } \\
(\text { SJG 107) } \\
\end{array}$} & Salvia & Gastritis & Leaves & Boiled, drink solution & 19 & 0.16 \\
\hline & & Anaemia & Leaves & Boiled, drink solution & & \\
\hline & & Menstrual colic & Leaves & Boiled, drink solution & & \\
\hline \multirow[t]{2}{*}{$\begin{array}{c}\text { Euphorbia } \\
\text { prostrata Aiton. } \\
\text { (SJG 066) }\end{array}$} & $\begin{array}{c}\text { Hierba de la } \\
\text { golondrina }\end{array}$ & Gastritis & Steam, leaves and flower & Boiled, drink solution & 4 & 0.03 \\
\hline & & Rash & Steam, leaves and flower & Boiled, wash & & \\
\hline \multicolumn{7}{|l|}{ Fabaceae } \\
\hline \multirow[t]{3}{*}{$\begin{array}{c}\text { Ebenopsis ebano } \\
\text { (Berland.) } \\
\text { Barneby \& J.W. } \\
\text { Grimes (SJG } \\
0109) \\
\end{array}$} & Ébano & Diarrhea & Tree bark & Boiled, drink solution & 2 & 0.01 \\
\hline & & Antioxidants & Seed & Boiled or toasted & & \\
\hline & & Diabetes & Seed & Boiled or toasted & & \\
\hline
\end{tabular}


Jasso-Gándara SN et al. (2020). Not Bot Horti Agrobo 48(3):1130-1140

\begin{tabular}{|c|c|c|c|c|c|c|}
\hline $\begin{array}{c}\text { Family / } \\
\text { Scientific name }\end{array}$ & $\begin{array}{l}\text { Common } \\
\text { name }\end{array}$ & Uses & Part used & Method of use & $\begin{array}{c}\text { Numbers } \\
\text { of use } \\
\text { reports }\end{array}$ & \begin{tabular}{|c|} 
Use \\
Value \\
(UV) \\
\end{tabular} \\
\hline $\begin{array}{c}\text { Dalea scandens } \\
\text { (Mill.) R.T. } \\
\text { Clausen (SJG } \\
0114 \text { ) } \\
\end{array}$ & $\begin{array}{l}\text { Hierba del } \\
\text { burro }\end{array}$ & Hemorrhoids & Leaves & Boiled, drink solution & 1 & 0.008 \\
\hline $\begin{array}{c}\text { Prosopis } \\
\text { glandulosa Torr. } \\
\text { (SJG 099) }\end{array}$ & Mezquite & Diarrhea & Tree bark and fruit peel & Boiled, drink solution & 5 & 0.04 \\
\hline $\begin{array}{l}\text { Senna sp. Mill. } \\
\text { (SJG 087) }\end{array}$ & Palo santo & Foot Fungi & Leaves and flower & Macerated with alcohol, wash & 1 & 0.008 \\
\hline Fagaceae & & & & & & \\
\hline \multirow[t]{4}{*}{$\begin{array}{c}\text { Quercus } \\
\text { polymorpha } \\
\text { Schltdl. \& } \\
\text { Cham. } \\
\text { (SJG 070) } \\
\end{array}$} & $\begin{array}{l}\text { Encino } \\
\text { prieto }\end{array}$ & Diarrhea & Tree bark & Fermented in water, drink solution & 2 & 0.017 \\
\hline & & Stomach ache & & Fermented in water, drink solution & & \\
\hline & & Oral infections & & Fermented in water, mouthwash & & \\
\hline & & Kidney diseases & & Fermented in water, drink solution & & \\
\hline \multicolumn{7}{|l|}{ Hydrangeaceae } \\
\hline $\begin{array}{c}\text { Hydrangea } \\
\text { macrophylla } \\
\text { (Thunb.) Ser. } \\
\text { (SJG 020) }\end{array}$ & Hortensia & $\begin{array}{l}\text { Prevent disease (helps the } \\
\text { immune system) }\end{array}$ & Root & Fermented in water, drink solution & 1 & 0.008 \\
\hline \multicolumn{7}{|l|}{ Juglandaceae } \\
\hline $\begin{array}{c}\text { Carya } \\
\text { illinoinensis } \\
\text { (Wangenh.) K. } \\
\text { Koch. (SJG } \\
0108 \text { ) }\end{array}$ & Nogal & Anaemia & Tree bark & Boiled, drink solution & 5 & 0.04 \\
\hline \multicolumn{7}{|l|}{ Krameriaceae } \\
\hline \multirow[t]{2}{*}{\begin{tabular}{|c|} 
Krameria \\
ramosissima (A. \\
Gray) S. Watson \\
(SJG O117) \\
\end{tabular}} & Calderona & $\begin{array}{c}\text { Anti-inflammatory of } \\
\text { stomach }\end{array}$ & Leaves & Boiled, drink solution & 4 & 0.03 \\
\hline & & Kidney diseases & Root & Boiled, drink daily as infusion & & \\
\hline \multicolumn{7}{|l|}{ Lamiaceae } \\
\hline \multirow[t]{2}{*}{$\begin{array}{c}\text { Hedeoma } \\
\text { drummondii } \\
\text { Benth. } \\
\text { (SJG 064) } \\
\end{array}$} & Poleo & Insomnia & Leaves & $\begin{array}{l}\text { Put under the pillow, released oils } \\
\text { can produce relaxation and sleep }\end{array}$ & 5 & 0.04 \\
\hline & & Cough & Leaves & Boiled, drink solution & & \\
\hline \multirow[t]{2}{*}{$\begin{array}{c}\text { Hedeoma } \\
\text { palmeri Hemsl. } \\
\text { (SJG 045). } \\
\end{array}$} & Poleo & Insomnia & Leaves & $\begin{array}{l}\text { Put under the pillow, released oils } \\
\text { can produce relaxation and sleep }\end{array}$ & 3 & 0.02 \\
\hline & & Cough & Leaves & Boiled, drink solution & & \\
\hline $\begin{array}{l}\text { Majorana } \\
\text { hortensis } \\
\text { Moench. } \\
\text { (SJG 048) }\end{array}$ & Mejorana & Stomach ache & Stems and leaves & Boiled, drink solution & 1 & 0.008 \\
\hline \multirow[t]{4}{*}{$\begin{array}{l}\text { Marrubium } \\
\text { vulgare L. } \\
\text { (SJG 022) } \\
\end{array}$} & Marrubio & Increases appetite & Leaves & Boiled, drink solution & 26 & 0.22 \\
\hline & & Diarrhea & Leaves & Boiled, drink solution & & \\
\hline & & Stomach ache & Leaves & Boiled, drink solution & & \\
\hline & & Cough & Leaves & Boiled, drink solution & & \\
\hline $\begin{array}{l}\text { Menthax } \\
\text { piperita L. } \\
\text { (SJG 038) }\end{array}$ & Menta & Stomach ache & Leaves & Boiled, drink solution & 2 & 0.01 \\
\hline $\begin{array}{l}\text { Mentha spicata } \\
\text { L. (SJG 017) }\end{array}$ & Yerbabuena & Menstrual colic & Leaves & Boiled, drink solution & 44 & 0.38 \\
\hline
\end{tabular}


Jasso-Gándara SN et al. (2020). Not Bot Horti Agrobo 48(3):1130-1140

\begin{tabular}{|c|c|c|c|c|c|c|}
\hline $\begin{array}{c}\text { Family / } \\
\text { Scientific name }\end{array}$ & $\begin{array}{l}\text { Common } \\
\text { name }\end{array}$ & Uses & Part used & Method of use & $\begin{array}{c}\text { Numbers } \\
\text { of use } \\
\text { reports }\end{array}$ & $\begin{array}{l}\text { Use } \\
\text { Value } \\
\text { (UV) } \\
\end{array}$ \\
\hline & & $\begin{array}{l}\text { Anti-inflammatory } \\
\text { of stomach }\end{array}$ & Leaves & Boiled, drink solution & & \\
\hline & & Toothache & Leaves & Boiled, mouthwash & & \\
\hline & & Stomach ache & Leaves & Boiled, drink solution & & \\
\hline & & Intestinal parasites & Leaves & Boiled, drink solution & & \\
\hline & & Vomit & Leaves & Boiled, drink solution & & \\
\hline \multirow[t]{8}{*}{$\begin{array}{c}\text { Ocimum } \\
\text { basilicum L. } \\
\text { (SJG 080) }\end{array}$} & Albacar & $\begin{array}{l}\text { Anti-inflammatory of } \\
\text { stomach }\end{array}$ & Leaves & Boiled, drink solution & 22 & 0.19 \\
\hline & & Stomach ache & Leaves & Boiled, drink solution & & \\
\hline & & Stress & Leaves & Boiled, drink solution & & \\
\hline & & Foot Fungi & Leaves & Boiled, wash & & \\
\hline & & $\begin{array}{l}\text { Remove bad luck and } \\
\text { cleanse soul }\end{array}$ & Leaves & $\begin{array}{l}\text { Touching the body of person with } \\
\text { leaves }\end{array}$ & & \\
\hline & & Vomit & Leaves & Boiled, drink solution & & \\
\hline & & Bad breath & Leaves & Boiled, mouthwash & & \\
\hline & & Digestive & Leaves & Boiled, drink solution & & \\
\hline $\begin{array}{c}\text { Poliomintha } \\
\text { longiflora A. } \\
\text { Gray (SJG 053) }\end{array}$ & Orégano & Cough & Leaves & Boiled, drink solution & 19 & 0.16 \\
\hline \multirow[t]{6}{*}{$\begin{array}{c}\text { Rosmarinus } \\
\text { officinalis } \mathrm{L} \text {. } \\
\text { (SJG 05) } \\
\end{array}$} & Romero & Menstrual colic & Stems and leaves & Boiled, drink solution & 16 & 0.13 \\
\hline & & Diarrhea & Stems and leaves & Boiled, drink solution & & \\
\hline & & Sunken fontanelle & Stems and leaves & $\begin{array}{l}\text { Boiled, put in a vessel, take the baby } \\
\text { and place it with the head down, } \\
\text { press the palate and touch the } \\
\text { solution with the baby's head }\end{array}$ & & \\
\hline & & Stomach ache & Stems and leaves & Boiled, drink solution & & \\
\hline & & Rash & Stems and leaves & Boiled, wash & & \\
\hline & & $\begin{array}{l}\text { Remove bad luck and } \\
\text { cleanse soul }\end{array}$ & Stems and leaves & $\begin{array}{l}\text { Touching the body of person with } \\
\text { leaves }\end{array}$ & & \\
\hline \multirow[t]{7}{*}{$\begin{array}{l}\text { Teucrium } \\
\text { cubense Jacq. } \\
\text { (SJG 040) }\end{array}$} & Verbena & Diarrhea & Stems and leaves & Boiled, drink solution & 13 & 0.11 \\
\hline & & Headache & Stems and leaves & Macerated in water, drink solution & & \\
\hline & & Stomach ache & Stems and leaves & Boiled, drink solution & & \\
\hline & & Fever & Stems and leaves & Macerated in water, drink solution & & \\
\hline & & Rash & Stems and leaves & Boiled, wash & & \\
\hline & & Typhoid & Stems and leaves & Macerated in water, drink solution & & \\
\hline & & Gastritis & Stems and leaves & Boiled, drink solution & & \\
\hline \multicolumn{7}{|l|}{ Lauraceae } \\
\hline $\begin{array}{c}\text { Litsea } \\
\text { glaucescens } \\
\text { Kunth (SJG } \\
065) \\
\end{array}$ & Laurel & Dizziness & Leaves & Boiled, drink solution & 3 & 0.02 \\
\hline \multicolumn{7}{|l|}{ Lythraceae } \\
\hline $\begin{array}{c}\text { Punica } \\
\text { granatum L. } \\
\text { (SJG 073) }\end{array}$ & Granada & Diarrhea & Fruit peel and leaves & Boiled, drink solution & 2 & 0.01 \\
\hline \multicolumn{7}{|l|}{ Malvaceae } \\
\hline $\begin{array}{l}\text { Abutilon } \\
\text { fruticosum } \\
\text { Guill. \& Perr. } \\
\text { (SJG 042) } \\
\end{array}$ & Catana & Kidney diseases & Root & Boiled, drink solution & 1 & 0.008 \\
\hline $\begin{array}{l}\text { Malva parviflora } \\
\text { L. (SJG 010) }\end{array}$ & Malva & External wounds & Leaves & Boiled, wash & 3 & 0.02 \\
\hline
\end{tabular}


Jasso-Gándara SN et al. (2020). Not Bot Horti Agrobo 48(3):1130-1140

\begin{tabular}{|c|c|c|c|c|c|c|}
\hline $\begin{array}{c}\text { Family / } \\
\text { Scientific name }\end{array}$ & $\begin{array}{c}\text { Common } \\
\text { name }\end{array}$ & Uses & Part used & Method of use & \begin{tabular}{|c|}
$\begin{array}{c}\text { Numbers } \\
\text { of use } \\
\text { reports }\end{array}$ \\
\end{tabular} & \begin{tabular}{|c|} 
Use \\
Value \\
(UV) \\
\end{tabular} \\
\hline & & Removing thorns & Leaves & $\begin{array}{c}\text { Boiled, put the solution several } \\
\text { times with a flannel in the affected } \\
\text { area }\end{array}$ & & \\
\hline & & External pains & Leaves & $\begin{array}{c}\text { Boiled, put the solution several } \\
\text { times with a flannel in the affected } \\
\text { area }\end{array}$ & & \\
\hline \multicolumn{7}{|l|}{ Meliaceae } \\
\hline \multirow[t]{3}{*}{$\begin{array}{c}\text { Azadirachta } \\
\text { indica A. Juss. } \\
\text { (SJG 056) }\end{array}$} & $\mathrm{Nim}$ & Diabetes & Leaves & Boiled, 2 or 3 leaves, drink solution & 26 & 0.22 \\
\hline & & Stomach ache & Leaves & Boiled, 2 or 3 leaves, drink solution & & \\
\hline & & Foot Fungi & Leaves & Boiled and wash & & \\
\hline \multicolumn{7}{|l|}{ Moraceae } \\
\hline $\begin{array}{l}\text { Ficus carica L. } \\
\text { (SJG 032) }\end{array}$ & Higo & Varicose veins & Fruit & Macerated, like cataplasm & 1 & 0.008 \\
\hline \multicolumn{7}{|l|}{ Moringaceae } \\
\hline $\begin{array}{l}\text { Moringa oleifera } \\
\text { Lam. (SJG 082) }\end{array}$ & Moringa & Diabetes & Leaves & Boiled, drink solution & 1 & 0.008 \\
\hline \multicolumn{7}{|l|}{ Myrtaceae } \\
\hline $\begin{array}{c}\text { Eucalyptus } \\
\text { globulus Labill. } \\
\text { (SJG 097) } \\
\end{array}$ & Eucalipto & Cough & Leaves & Boiled, drink solution & 15 & 0.13 \\
\hline \multirow[t]{2}{*}{$\begin{array}{c}\text { Psidium guajava } \\
\text { L. (SJG 0106) }\end{array}$} & Guayaba & Diarrhea & Leaves & Boiled, drink solution & 25 & 0.21 \\
\hline & & Stomach ache & Leaves & Boiled, drink solution & & \\
\hline \multicolumn{7}{|l|}{ Nyctaginaceae } \\
\hline \multirow[t]{2}{*}{$\begin{array}{c}\text { Boerhavia } \\
\text { spicata Choisy } \\
\text { (SJG 057) } \\
\end{array}$} & $\begin{array}{c}\text { Hierba de la } \\
\text { hormiga }\end{array}$ & Rash & Stems and leaves & Boiled, wash & 3 & 0.02 \\
\hline & & Kidney diseases & Stems and leaves & Boiled, drink solution & & \\
\hline \multirow[t]{2}{*}{$\begin{array}{c}\text { Bougainvillea } \\
\text { glabra Choisy } \\
\text { (SJG 052) }\end{array}$} & Buganvilia & Asthma & Flower & Boiled, drink solution & 16 & 0.13 \\
\hline & & Cough & Flower & Boiled, drink solution & & \\
\hline \multicolumn{7}{|l|}{ Onagraceae } \\
\hline $\begin{array}{c}\text { Oenothera } \\
\text { brachycarpa A. } \\
\text { Gray (SJG } \\
0113) \\
\end{array}$ & $\begin{array}{c}\text { Hierba de la } \\
\text { culebra }\end{array}$ & Herpes virus & Leaves & Cooked, macerated as cataplasm & 1 & 0.008 \\
\hline $\begin{array}{c}\text { Oenothera rosea } \\
\text { L'Hér. ex Aiton } \\
\text { (SJG 059) }\end{array}$ & $\begin{array}{l}\text { Hierba del } \\
\text { golpe }\end{array}$ & Bangs & Leaves & Macerated, like cataplasm & 7 & 0.06 \\
\hline \multicolumn{7}{|l|}{ Papaveraceae } \\
\hline $\begin{array}{l}\text { Argemone } \\
\text { mexicana L. } \\
\text { (SJG 011) }\end{array}$ & Chicalote & Eye Infection & Sap & Mix with milk, smear on the eyes & 1 & 0.008 \\
\hline \multicolumn{7}{|l|}{ Passifloraceae } \\
\hline $\begin{array}{l}\text { Turnera diffusa } \\
\text { Willd. ex Schult. } \\
\text { (SJG 0116) }\end{array}$ & $\begin{array}{l}\text { Hierba del } \\
\text { venado }\end{array}$ & Fertility & Stems and leaves & Boiled, drink solution & 3 & 0.02 \\
\hline \multicolumn{7}{|l|}{ Poaceae } \\
\hline \multirow[t]{2}{*}{\begin{tabular}{|c|} 
Cymbopogon \\
citratus (DC.) \\
Stapf (SJG 039) \\
\end{tabular}} & Zacate limón & $\begin{array}{c}\text { Anti-inflammatory of } \\
\text { stomach }\end{array}$ & Leaves & Boiled, drink solution & 8 & 0.06 \\
\hline & & Vomit & Leaves & Boiled, drink solution & & \\
\hline $\begin{array}{c}\text { Cynodon } \\
\text { dactylon (L.) } \\
\text { Pers. (SJG 027) }\end{array}$ & Gramilla & Digestive & Stems and leaves & $\begin{array}{c}\text { Mix with chamomile and rue, apply } \\
\text { some heat, place on a flannel with } \\
\text { ashes and pieces of brick, put over } \\
\text { the stomach }\end{array}$ & 3 & 0.02 \\
\hline
\end{tabular}


Jasso-Gándara SN et al. (2020). Not Bot Horti Agrobo 48(3):1130-1140

\begin{tabular}{|c|c|c|c|c|c|c|}
\hline $\begin{array}{c}\text { Family / } \\
\text { Scientific name }\end{array}$ & $\begin{array}{l}\text { Common } \\
\text { name }\end{array}$ & Uses & Part used & Method of use & \begin{tabular}{|c|}
$\begin{array}{c}\text { Numbers } \\
\text { of use } \\
\text { reports }\end{array}$ \\
\end{tabular} & $\begin{array}{l}\text { Use } \\
\text { Value } \\
\text { (UV) }\end{array}$ \\
\hline \multicolumn{7}{|l|}{ Rosaceae } \\
\hline $\begin{array}{l}\text { Crataegus tracyi } \\
\text { Ashe ex Eggl. } \\
\text { (SJG 0126) }\end{array}$ & Tejocote & Kidney diseases & Root & Fermented in water, drink solution & 6 & 0.05 \\
\hline \multirow[t]{2}{*}{$\begin{array}{c}\text { Rosa gallica L. } \\
\text { (SJG 0102) }\end{array}$} & $\begin{array}{l}\text { Rosa de } \\
\text { castilla }\end{array}$ & Diarrhea & Flower & Boiled, drink solution & 5 & 0.04 \\
\hline & & Stomach ache & Flower & Boiled, drink solution & & \\
\hline \multicolumn{7}{|l|}{ Rubiaceae } \\
\hline $\begin{array}{c}\text { Randia } \\
\text { rhagocarpa } \\
\text { Standl. } \\
\text { (SJG 0103) }\end{array}$ & Brasil & Diabetes & Stems and leaves & Boiled, drink solution & 2 & 0.01 \\
\hline \multicolumn{7}{|l|}{ Rutaceae } \\
\hline \multirow[t]{3}{*}{$\begin{array}{l}\text { Citrus sp. L. } \\
\text { (SJG 086) }\end{array}$} & $\begin{array}{c}\text { Naranjo } \\
\text { agrio }\end{array}$ & Nervous & Leaves & Boiled, drink solution & 1 & 0.008 \\
\hline & & Insomnia & Leaves & Boiled, drink solution & & \\
\hline & & Cough & Leaves & Boiled, drink solution & & \\
\hline \multirow[t]{2}{*}{$\begin{array}{c}\text { Murraya } \\
\text { paniculata (L.) } \\
\text { Jack (SJG 084) }\end{array}$} & Limonaria & Diabetes & Stems and leaves & Boiled, drink solution & 1 & 0.008 \\
\hline & & Intestinal parasites & Stems and leaves & Boiled, drink solution & & \\
\hline \multirow[t]{7}{*}{$\begin{array}{c}\text { Ruta graveolens } \\
\text { L. (SJG 030) }\end{array}$} & Ruda & Menstrual colic & Stems and leaves & Boiled, drink solution & 28 & 0.2 \\
\hline & & Digestive & Stems and leaves & Boiled, drink solution & & \\
\hline & & Headache & Stems and leaves & Boiled, drink solution & & \\
\hline & & Stomach ache & Stems and leaves & Boiled, drink solution & & \\
\hline & & Dizziness & Stems and leaves & Boiled, drink solution & & \\
\hline & & $\begin{array}{l}\text { Remove bad luck and } \\
\text { cleanse soul }\end{array}$ & Stems and leaves & $\begin{array}{l}\text { Touching the body of the person } \\
\text { with leaves and inhale the steam } \\
\text { boiled leaves }\end{array}$ & & \\
\hline & & Abortive & Stems and leaves & Boiled, drink solution & & \\
\hline $\begin{array}{c}\text { Zanthoxylum } \\
\text { fagara (L.) Sarg. } \\
\text { (SJG 0122) }\end{array}$ & Uña de gato & Kidney diseases & Tree bark & Boiled, drink solution & 1 & 0.008 \\
\hline \multicolumn{7}{|l|}{ Scrophulariaceae } \\
\hline \multirow[t]{2}{*}{$\begin{array}{l}\text { Leucophyllum } \\
\text { revolutum Rzed. } \\
\text { (SJG 049) }\end{array}$} & Cenizo & Rash & Stems and leaves & Boiled, wash & 3 & 0.02 \\
\hline & & Stomach ache & Stems and leaves & Boiled, drink solution & & \\
\hline \multicolumn{7}{|l|}{ Selaginellaceae } \\
\hline \multirow[t]{3}{*}{$\begin{array}{c}\text { Selaginella } \\
\text { lepidophylla } \\
\text { (Hook. \& Grev.) } \\
\text { Spring (SJG 06) } \\
\end{array}$} & Flor de peña & Kidney diseases & Whole plant & Fermented in water, drink solution & 5 & 0.04 \\
\hline & & Urinary infections & Whole plant & Fermented in water, drink solution & & \\
\hline & & Ulcers & Whole plant & Fermented in water, drink solution & & \\
\hline \multicolumn{7}{|l|}{ Simaroubaceae } \\
\hline \multirow[t]{2}{*}{$\begin{array}{c}\text { Castela erecta } \\
\text { Turpin } \\
\text { (SJG 076) } \\
\end{array}$} & Bizbirinda & Constipation & Stems and leaves & Boiled, drink solution & 13 & 0.11 \\
\hline & & Stomach ache & Stems and leaves & Boiled, drink solution & & \\
\hline \multicolumn{7}{|l|}{ Smilacaceae } \\
\hline $\begin{array}{l}\text { Smilax bona-nox } \\
\text { L. (SJG 058) }\end{array}$ & $\begin{array}{l}\text { Hierba del } \\
\text { ojo }\end{array}$ & $\begin{array}{c}\text { Remove bad luck and } \\
\text { cleanse soul }\end{array}$ & Stems and leaves & $\begin{array}{c}\text { Touching the body of person with } \\
\text { leaves }\end{array}$ & 3 & 0.02 \\
\hline \multicolumn{7}{|l|}{ Solanaceae } \\
\hline \multirow[t]{2}{*}{$\begin{array}{c}\text { Cestrum } \\
\text { tomentosum L.f. } \\
(\text { SJG 019) } \\
\end{array}$} & $\begin{array}{c}\text { Palo } \\
\text { hediondo }\end{array}$ & $\begin{array}{l}\text { Remove bad luck and } \\
\text { cleanse soul }\end{array}$ & Stems and leaves & $\begin{array}{c}\text { Touching the body of person with } \\
\text { leaves }\end{array}$ & 5 & 0.04 \\
\hline & & Rash & Leaves & Macerated, wash with solution & & \\
\hline
\end{tabular}


Jasso-Gándara SN et al. (2020). Not Bot Horti Agrobo 48(3):1130-1140

\begin{tabular}{|c|c|c|c|c|c|c|}
\hline $\begin{array}{c}\text { Family / } \\
\text { Scientific name }\end{array}$ & $\begin{array}{c}\text { Common } \\
\text { name }\end{array}$ & Uses & Part used & Method of use & \begin{tabular}{|c|}
$\begin{array}{c}\text { Numbers } \\
\text { of use } \\
\text { reports }\end{array}$ \\
\end{tabular} & \begin{tabular}{|l|} 
Use \\
Value \\
(UV) \\
\end{tabular} \\
\hline $\begin{array}{c}\text { Solanum } \\
\text { americanum } \\
\text { Mill. (SJG 01) } \\
\end{array}$ & Hierba mora & External wounds & Steam, leaves and flower & Boiled, mouthwash & 1 & 0.008 \\
\hline \multicolumn{7}{|l|}{ Verbenaceae } \\
\hline $\begin{array}{c}\text { Aloysia } \\
\text { citriodora Palau } \\
\text { (SJG 062) }\end{array}$ & $\begin{array}{l}\text { Cedrón de } \\
\text { castilla }\end{array}$ & Stomach ache & Leaves & Boiled, drink solution & 3 & 0.02 \\
\hline $\begin{array}{c}\text { Glandularia } \\
\text { bipinnatifida } \\
\text { (Schauer) Nutt. } \\
\text { (SJG 063) }\end{array}$ & Moradilla & $\begin{array}{l}\text { Remove bad luck and } \\
\text { cleanse soul }\end{array}$ & Whole plant & $\begin{array}{l}\text { Touching the body of the person } \\
\text { with leaves then put these in water, } \\
\text { if the water consistency is } \\
\text { gelatinous, the evil will come out }\end{array}$ & 2 & 0.01 \\
\hline & & Hair loss & Whole plant & Macerated, wash hair daily & & \\
\hline \multicolumn{7}{|l|}{ Viburnaceae } \\
\hline $\begin{array}{l}\text { Sambucus nigra } \\
\text { L. (SJG 031) }\end{array}$ & Sauco & Cough & Flower & Boiled, drink solution & 3 & 0.02 \\
\hline
\end{tabular}

